\title{
Implementasi Nilai-Nilai Tri Kaya Parisudha dalam Pembelajaran dengan Model Discovery Learning Berpengaruh Terhadap Kompetensi Pengetahuan IPA
}

\author{
Ni Ketut Desya Sapta Yanthi ${ }^{*}$, I Gusti Agung Oka Negara² iD \\ ${ }^{12}$ Prodi Pendidikan Guru Sekolah Dasar, Universitas Pendidikan Ganesha, Singaraja, Indonesia \\ *Corresponding author: ketut.desya.sapta@undiksha.ac.id
}

\begin{abstract}
Abstrak
Penelitian ini bertujuan mengkaji pengaruh model Discovery Learning Berbasis Tri Kaya Parisudha terhadap kompetensi pengetahuan IPA. Penelitian ini tergolong jenis penelitian kuantitatif dengan rancangan nonequivalent control group design. Populasi penelitian menggunakan seluruh siswa kelas V SD Negeri Gugus V Mengwi sebanyak 7 kelas dengan total 235 siswa. Teknik cluster random sampling digunakan untuk menentukan sampel penelitian. Sampel yang diperoleh sebanyak 68 siswa yaitu 38 siswa kelas V di SD No. 2 Buduk sebagai kelas eksperimen dan 30 siswa V di SD No. 3 Buduk termasuk kelas kontrol. Dalam mengumpulkan data kompetensi pengetahuan IPA menggunakan tes pilihan ganda biasa, yang kemudian dianalisis menggunakan analisis uji t polled varians. Berdasarkan hasil perhitungan diperoleh thitung $=5,779>t_{\text {tabel }}$ 2,000 pada taraf signikansi 5\% dengan $\mathrm{dk}=66$, sehingga Ho ditolak. Jadi berdasarkan hasil analisis dapat disimpulkan bahwa terdapat pengaruh model Discovery Learning Berbasis Tri Kaya Parisudha terhadap kompetensi pengetahuan IPA siswa kelas V SD Negeri Gugus V Mengwi tahun ajaran 2019/2020.
\end{abstract}

Keywords: Discovery Learning, Tri Kaya Parisudha, Kompetensi Pengetahuan IPA

\section{Abstract}

This study aims to determine the effect of the Discovery Learning model based Tri Kaya Parisudha on science knowledge competencies. This quantitative type of research using nonequivalent control group design. The study population is all fifth grade SD N Cluster V Buduk us many 7 classes with a total of 235 students. The sampel is determin by the random sampling technique. The total sample is 68 stundents with 38 students V at SD No. 2 Buduk as the experimental group and 30 students $V$ at SD No. 3 Buduk as the control group. In collecting science knowledge competencies data using a regular multiple choice test, which is then analyzed by polled variance $t$-test analysis. Analysis based on the results obtained $t_{\text {count }}=5,779>$ $t_{\text {table }}=2,000$ significance level of 5\% and $d k=68$, so that Ho is declined. So based on the results of the analysis it can be concluded that there is an influence of the Discovery Learning model based Tri Kaya Parisudha on the science knowledge competencies of fifth grade students at SD N Cluster V Mengwi in the Academic Year 2019/2020.

Keywords: Discovery Learning, Tri Kaya Parisudha, Science Knowledge Competencies

\section{Pendahuluan}

Pendidikan merupakan suatu proses pembelajaran pengetahuan, keterampilan dari kebiasaan manusia yang diwariskan dari satu generasi ke generasi selanjutnya melalui pelatihan dan pengajaran. Pendidikan merupakan salah satu bentuk perubahan dari perkembangan kebudayaan manusia. Oleh karena itu sudah seharusnya perubahan didalam pendidikan terus dilakukan mengikuti perkembangan zaman agar pendidikan tersebut lebih baik dari sebelumnya. Dalam Sistem Pendidikan Nasional menyatakan bahwa pendidikan memiliki tujuan untuk mengembangkan potensi peserta didik agar dapat menjadi manusia yang beriman dan bertakwa kepada Tuhan Yang Maha Esa, berakhlak mulia, berilmu, kreatif, dan mandiri, serta bertanggung jawab. Agar dapat terwujudnya tujuan dari pendidikan tersebut, maka disusunlah rencana tertulis yang dikenal dengan kurikulum. Saat ini pendidikan di Indonesia menggunakan kurikulum 2013.

Pada Sistem Pendidikan Nasional dijelaskan bahwa kurikulum merupakan pedoman penyelenggaraan kegiatan pembelajaran dalam suatu perangkat rencana untuk tujuan yang

$\begin{array}{lll}\text { History: } & \text { Publisher: Undiksha Press } \\ \text { Received } & : 4 \text { Maret } 2020 & \text { Licensed: This work is licensed under } \\ \text { Revised } & : 15 \text { Maret } 2020 & \text { a Creative Commons Attribution 3.0 License } \\ \text { Accepted } & : 26 \text { Maret } 2020 & \text { CC } \\ \text { Published } & : \text { April } 2020 & \text { SA }\end{array}$


dicapai. Tujuan kurikulum 2013 yaitu membantu masyarakat Indonesia dalam menyiapkan diri untuk memiliki kemampuan hidup agar dapat menjadi warga negara yang lebih baik. Pada proses pembelajaran Kurikulum 2013 siswa dituntut berperan aktif seperti mencari, mengolah, mengkontruksi serta menerapkan pengetahuan.

Permendikbud nomor 22 tahun 2016 pada bagian proses pembelajaran menyatakan bahwa proses pembelajaran pada masing-masing instansi pendidikan dapat dilakukan secara intraktif, inspiratif, diberi motivasi peserta didik agar dapat berpartisipasi dengan aktif sesuai dengan bakat, minat, dan perkembangan fisik peserta didik. Setiap satuan pendidikan melakukan perencanaan pembelajaran, pelaksanaan proses pembelajaran serta penilaian proses pembelajaran untuk meningkatkan efisiensi ketercapaian kompetensi lulusan, khususnya dalam kompetensi pengetahuan IPA. Kompetensi pengetahuan IPA adalah suatu ilmu pengetahuan yang mempelajari mempelajari peristiwa-peristiwa yang terjadi di alam, yang berhubungan satu sama lain dan didasarkan pada hasil observasi atau pengamatan serta dibangun atas dasar produk ilmiah, proses ilmiah, dan sikap ilmiah. Dalam mempelajari ilmu pengetahuan alam memerlukan konsentrasi penuh dan praktek dalam mempelajarinya. Pelajaran ilmu pengetahuan alam tidak bisa hanya dengan dipelajari saja, namun keaktifan dalam pembelajaran juga mempengaruhi kualitas pembelajaran ilmu pengetahuan alam tersebut. Ilmu pengetahuan alam diajarkan melalui kegiatan pembelajaran yang aktif dan menekankan pada keterampilan proses siswa. Dari penjelasan yang dipaparkan, tampaknya diperlukan suatu pembelajaran yang dapat membantu siswa agar terlibat aktif. Penggunaan model, metode dan strategi pembelajaran dalam kemampuan dan keterampilan guru saat pembelajaran perlu ditingkatkan agar pembelajaran IPA dapat mewujudkan kemampuan dan keterampilan dasar siswa dalam proses pembelajaran. Untuk dapat menciptakan keaktifan dalam pembelajaran, dibutuhkan seorang guru yang ahli dan bertanggungjawab dalam penyelenggaraan pendidikan disekolah. Selain itu keahlian guru dalam pengelolaan kelas yang baik dapat meningkatkan mutu pendidikan. Maka dari itu guru haruslah dapat merancang metode, model, dan strategi pembelajaan baik agar dapat meningkatkan keaktifan siswa dalam mengikuti pembelajaran.

Berdasarkan hasil observasi dan wawancara yang telah dilakukan di SD, khususnya pada mata pelajaran IPA, ditemukan bahwa dalam proses pembelajaran masih banyak siswa yang mengalami kesulitan dalam pembelajaran muatan IPA. Berkaitan dengan hal tersebut, banyak faktor yang memengaruhi salah satunya penerapan model pembelajaran serta media pembelajaran yang kurang beragam dalam menunjang proses pembelajaran. Cara pembelajaran yang demikian dapat membuat siswa pasif dan kurang semangat untuk mengikuti pembelajaran, itu terlihat dari kurangnya antusias siswa dalam menjawab pertanyaan yang diberikan oleh guru, hanya ada beberapa siswa yang antusias dalam mengikuti pembelajaran. Kurangnya penerapan model dan media saat pembelajaran dapat menghilangkan perhatian siswa terhadap pembelajaran. Selain itu siswa kurang percaya diri jika diberi kesempatan untuk bertanya atau mengemukakan pendapat, jika melakukan kesalahan siswa akan cenderung putus asa dan siswa lain akan mengejek siswa tersebut sehingga membuat metalnya menurun.Dari uraian tersebut, maka diperlukan berupa penerapan model pembelajaran yang bersifat aktif dan dapat menjaga etika siswa dalam berbuat, berkata, serta berpikir. Salah satunya model pembelajaran yang dapat diterapkan untk meningkatkan keaktifan siswa yaitu model pembelajaran Discovery Learning berbasis Tri Kaya Parisudha, dengan model ini siswa didorong untuk belajar sendiri melalui keterlibatan aktif dengan berbagai konsep dan prinsip melalui ajaran etika yang baik.

Model Discovery Learning merupakan model pembelajaran penemuan yang menggunakan pendekatan kontruktivis mentransformasikan informasi sedemikian sehingga ia menemukan informasi baru. Melalui model discovery learning, siswa secara aktif menyelidiki hubungan, mengumpulkan materi, dan digunakan dalam menemukan konsep 
atau prinsip pada suatu peristiwa tersebut. (Kodir, 2018). Kelebihan menggunkan mode ini yaitu siswa dapat mengembangkan self concept" pada dirinya, serta mendorong siswa untuk berpikir dan bekerja atas inisiatifnya sendiri, bersikap objektif, jujur, dan terbuka. Dengan menggunakan model ini, siswa dapat meningkatkan kompetensi pengetahuannya dengan lebih mudah. Dikarenakan akan banyak menemukan pendapat dan latar belakang yang berbeda dalam kelas, maka pengalaman belajar berasaskan ajaran etika melalui basis Tri Kaya Parisudha akan sangat baik diberikan kepada siswa. Pentingnya etika dalam penanaman sikap pendidikan adalah karena sesungguhnya etikalah yang merupakan hal utama dan pertama perlu diberikan dan ditindaklanjuti dalam pengelolaan pendidikan. Maka dari itu pendidikan perlu menerapkan penanaman etika secara jelas dan konsisten.

Pada ajaran agama hindu kata Tri Kaya Parisudha terdiri terdiri dari tiga kata yaitu Tri yang berarti tiga, Kaya yang berarti perbuatan atau prilaku dan Parisudha yang berarti amat disucikan. Jadi Tri Kaya Parisudha Artinya tiga perilaku manusia dalam bentuk pikiran, perkataan, dan perbuatan yang harus disucikan (Suhardana, 2007). Meskipun Tri Kaya Parisudha dalam ajaran umat beragama Hindu, tidak ada salahnya juga dibelajarkan pada umat lainnya. Karena selain melestarikan kearifan lokal yang ada di Bali, tetapi juga dapat mengajak umat lain dalam cakupan ini adalah siswa non hindu untuk dapat sama-sama belajar tentang beretika yang baik dan menghargai orang lain. Adapun bagian-bagian dari Tri Kaya Parisudha yaitu, pada bagian pertama adalah Manacika yang artinya berpikir yang baik. Sikap ini akan mengajak siswa untuk selalu memiliki pikiran yang baik (positif). Bagian kedua yaitu Wacika yang artinya berkata yang baik. Sifat Wacika ini mengajarkan siswa untuk saling berkata yang baik, benar dan sopan terhadap sesama agar tidak menyakiti perasaan siapapun. Dan bagian yang ketiga adalah Kayika, yang artinya berbuat yang baik. Sifat ini mengajarkan siswa untuk selalu memperlihatkan perbuatan baik sebagai cerminan dari buah pikiran dan wacana, diharapkan akan terjadi interaksi yang positif dalam kehidupan sehari-hari. Dari penjelasan tersebut, proses pembelajaran menggunakan implementasi ajaran Tri Kaya Parisudha dapat mengajak siswa untuk selalu berpikir postif, berkata yang sopan, serta selalu berbuat yang baik melalui ajaran Tri Kaya Parisudha.

Pembelajaran dengan menggunakan model Discovery Learning berbasis Tri Kaya Parisudha memberikan pengalaman belajar bagi siswa dalam memperoleh informasi yang belum diketahuinya dengan jalan menemukan informasi baik secara sebagian maupun menyeluruh dan berlandaskan dengan perbuatan yang luhur, berkata yang baik dan sopan, serta berpikir yang positif dan menyadari bahwa semua makhluk adalah sama, yaitu ciptaan Tuhan. Bedasarkan uraian tersebut, maka penelitian ini bertujuan untuk menganalisis pengaruh model Discovery Learning berbasis Tri Kaya Parisudha terhadap kompetensi pengetahuan IPA siswa kelas V SD Negeri Gugus V Mengwi Tahun Ajaran 2019/2020.”

\section{Metode}

Berdasarkan jenis penelitian yang dilakukan ini merupakan penelitian kuantitatif desain quasi eksperiment (eksperimen semu). Bentuk desain tersebut ialah Nonequivalent Control Group Design. Rancangan diformulasikan sebagai berikut.

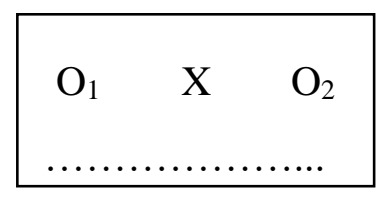

Gambar 1. Nonequivalent Control Group Design

(Sumber : Sugiyono, 2017:138)

Keterangan :

$\mathrm{O}_{1}=$ Pre test pada kelompok eksperimen sebelum diberi perlakuan 
$\mathrm{O}_{2}=$ Post test pada kelompok eksperimen setelah diberi perlakukan

$\mathrm{O}_{3}=$ Pre test pada kelompok kontrol sebelum dibelajarkan

$\mathrm{O}_{4}=$ Post test pada kelompok kontrol setelah dibelajarkan

$\mathrm{X}=$ Perlakuan dengan model pembelajaran Discovery Learning Berbasis Tri Kaya Parisudha yang diberikan kepada kelompok eksperimen. Sedangkan kelompok kontrol dibelajarkan melalui pembelajaran konvensional

Populasi penelitian terdiri dari 6 kelas dengan banyak siswa 235 orang. Penentuan sampel dilaksanakan melalui teknik cluster random sampling. Teknik cluster random sampling yakni teknik yang pemilihan sampelnya tidak mempertimbangkan secara perorangan, namun didasarkan pada kelompok (Sukardi, 2012). Sehingga setiap kelas memiliki peluang yang sama untuk menjadi sampel penelitian. Karena tidak dapat mengubah kelas yang telah terbentuk sebelumnya, kelas dipilih sebagaimana telah terbentuk tanpa campur tangan peneliti dan tidak dilakukannya pengacakan individu, maka kemungkinan pengaruh-pengaruh dari keadaan siswa mengetahui dirinya dilibatkan dalam eksperimen dapat dikurangi sehingga penelitian ini benar-benar menggambarkan pengaruh perlakuan. Maka dari itu dilaksanakan pengundian seluruh kelompok sehingga diperoleh 2 kelompok yang menjadi sampel penelitian. Pengambilan sampel tersebut memperoleh kelas V SD No. 2 Buduk yang ditetapkan sebagai kelompok eksperimen dengan jumlah 38 siswa dan kelas V SD N0. 3 Buduk yang ditetapkan sebagai kelompok kontrol yang berjumlah 30 siswa. Setelah mendapatkan 2 kelas tersebut, diberikan pre test dengan tujuan penyetaraan kelompok penelitian yang menjadi tolak ukur untuk memperoleh nilai kompetensi pengetahuan IPA.

Data yang dikumpulkan pada penelitian ini yakni data kompetensi pengetahuan IPA siswa. Pengumpulan data penelitian menggunakan metode tes. Jenis tes yang digunakan pada penelitian ini yakni tes objektif dengan bentuk pilihan ganda biasa. Tes objektif adalah tes yang disusun sedemikian rupa dan telah disediakan alternatif jawabannya. Dalam tes pilihan ganda biasanya menyediakan alternatif kemungkinan jawaban yaitu a, b, c, ataupun d (Arikunto, 2018). Siswa yang menjawab dengan benar butir tes mendapat skor yakni 1 dan siswa menjawab dengan salah butir tes mendapatkan skor yakni 0 . Tes pilihan ganda disusun sesuai kisi-kisi soal yang memuat KD dan indikator. Berikut ini disajikan kisi-kisi tes kompetensi pengetahuan IPA kelas V. Tabel kisi-kisi tes yang disajikan telah melalui proses uji coba butir tes sehingga diperoleh tes kompetensi pengetahuan IPA yang valid dengan uji korelasi point biserial yaitu sebanyak 30 soal. Dari uji daya beda diperoleh 20 butir soal kategori cukup, 8 butir soal kategori baik dan 2 butir soal kategori sangat baik. Dari uji tingkat kesukaran memperoleh 6 butir soal kategori sukar, 19 butir soal kategori sedang dan 5 butir soal kategori mudah dan uji reliabilitas menggunakan KR-20 memperoleh soal kompetensi pengetahuan IPA reliabel. Metode analisis data yakni metode analisis statistik inferensial yakni uji t. Sebelum uji t dilakukan maka dilaksanakan uji prasyarat yakni uji normalitas dan uji homogenitas. Adapun analisis Kolmogorov-Smirnov untuk menghitung normalitas data serta Uji Fisher dipergunakan untuk uji homogenitas pada penelitian ini. Kriteria pengujian normalitas data yakni $\mathrm{D}_{\text {hitung }}<\mathrm{D}_{\text {tabel }}$ Kolmogorov Smirnov berarti data berdistribusi normal dan kriteria uji homogenitas apabila Fhitung < F tabel berarti homogen sehingga uji hipotesis yaitu uji beda mean menggunakan statistik parametrik. Perhitungan analisis data pada penelitian ini menggunakan Microsoft Excel 2010.

\section{Hasil dan Pembahasan}

Data hasil kompetensi pengetahuan IPA didapatkan dari gain skor dengan menganalisis data pre test dan post test kedua kelompok. Pada penelitian ini, data yang diperoleh dibagi menjadi 2 yaitu data kompetensi pengetahuan IPA kelompok eksperimen 
dan data kompetensi pengetahuan kelompok kontrol. Data gain skor ternormalisasi kompetensi pengetahuan IPA kelompok eksperimen di peroleh rata-rata sebesar 0,719, standar deviasi sebesar 0,091, varians sebasar 0,008, nilai gain skor ternormalisasi minimum sebesar 0,001, dan nilai gain skor ternormalisasi maksimum sebesar 0,073. Perhitungan PAN skala 5 (lima) pada kelompok eksperimen berada pada predikat cukup. Sedangkan, data gain skor ternormalisasi kompetensi pengetahuan IPA kelompok kontrol di peroleh rata-rata sebesar 0,586, standar deviasi sebesar 0,099, varians sebasar 0,010, nilai gain skor ternormalisasi minimum sebesar 0,002 , dan nilai gain skor ternormalisasi maksimum sebesar 0,138. Perhitungan PAN skala 5 (lima) pada kelompok eksperimen berada pada predikat cukup.

Selanjutnya, dilakukan uji prasyarat yaitu uji normalitas sebaran data dan uji homogenitas varians. Uji normalitas sebaran data kompetensi pengetahuan IPA berfungsi untuk mengetahui data yang diperoleh dari penelitian saat uji hipotesis berditribusi normal atau tidak. Berdasarkan hasil uji normalitas sebaran data kelompok eksperimen, diperoleh

harga nilai maksimum $\| \boldsymbol{F}_{\boldsymbol{r}}-\boldsymbol{F}_{\boldsymbol{s}} \mid=0,073$ dan harga tabel Kolmogorov-Smirnov untuk taraf signifikan 5\% $(\alpha=0,05)=0,215$ karena nilai harga nilai maksimum $\left|\boldsymbol{F}_{\boldsymbol{r}}-\boldsymbol{F}_{\boldsymbol{s}}\right| \leq$ harga tabel Kolmogorov-Smirnov maka sebaran data gain skor ternormalisasi berdistribusi normal. Sedangkan hasil uji normalitas sebaran data kelompok kontrol yaitu harga nilai maksimum

$\left|\boldsymbol{F}_{\boldsymbol{r}}-\boldsymbol{F}_{\boldsymbol{s}}\right|=0,138$ dan harga tabel Kolmogorov-Smirnov untuk taraf signifikan 5\% $(\alpha=$ $0,05)=0,215$ karena harga nilai maksimum $\left|\boldsymbol{F}_{\boldsymbol{r}}-\boldsymbol{F}_{\boldsymbol{s}}\right| \leq$ harga tabel Kolmogorov-Smirnov maka sebaran data gain skor ternormalisasi berdistribusi normal.

Kemudian, uji homogenitas varians dilakukan berdasarkan data kompetensi pengetahuan IPA yang menggunakan data gain skor ternormalisasi kelompok eksperimen dan kelompok kontrol. Berdasarkan hasil perhitungan, diperoleh $F_{\text {hitung }}=1,25$. Sedangkan $F_{\text {tabel }}=$ 3,99. Dengan taraf signifikan 5\% $(\alpha=0,05)$ dengan df1 $=2-1=1$ dan df $268-2=66$. Maka nilai $\mathrm{F}_{\text {hitung }}=1,25<\mathrm{F}_{\text {tabel }}=3,99$, sehingga dapat dinyatakan data gain skor ternormalisasi kompetensi pengetahuan IPS memiliki varians yang homogen.

Tabel 1. Uji Homogenitas Varians Kelompok Eksperimen dan Kelompok Kontrol

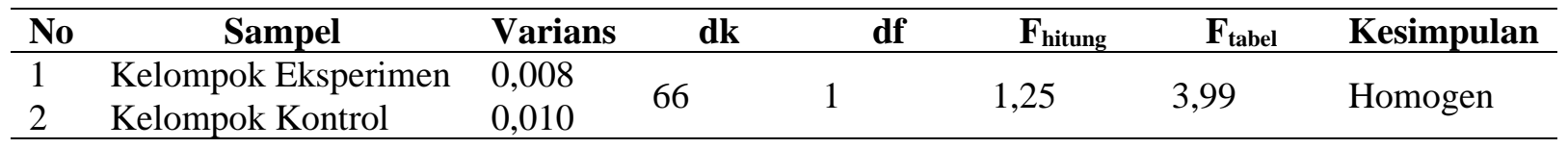

Setelah mengetahui data kompetensi pengetahuan IPA berdistribusi normal dan homogen maka selanjutnya dianalisis menggunakan uji statistik berupa uji $\mathrm{t}$ dengan rumus polled varian. Berdasarkan hasil peritungan hasil analisi uji t diperoleh 5,779 dan untuk taraf signifikan $5 \%$ dengan $\mathrm{dk}=(38+30-2)=66$ diperoleh $\mathrm{t}_{\text {tabel }}=2,000$. Dengan kriteria $\mathrm{t}_{\text {hitung }}>$ $\mathrm{t}_{\text {tabel }}$ yaitu $\mathrm{t}_{\text {hitung }}=5,779>\mathrm{t}_{\text {tabel }}=2,000$ maka, $\mathrm{H}_{\mathrm{o}}$ yang berbunyi tidak terdapat perbedaan model discovery learning berbasis tri kaya parisudha terhadap kompetensi pengetahuan IPA siswa kelas V SD Negeri Gugus V Mengwi ditolak (gagal diterima). Berdasarkan hasil analisis diperoleh diperoleh perbedaan yang signifikan kompetensi pengetahuan IPA siswa kelompok eksperimen yang dibelajarkan dengan model Discovery Learning berbasis Tri Kaya Parisudha dan kelompok kontrol yang dibelajarkan dengan pembelajaran konvensional dengan kata lain variabel bebas yaitu model Discovery Learning berbasis Tri Kaya Parisudha memiliki pengaruh terhadap variabel terikat yaitu kompetensi pengetahuan IPA siswa kelas V 
SD Negeri Gugus V Mengwi. Hasil analisis uji t pada sampel penelitian ini disajikan sebagai berikut.

Tabel 2. Rekapitulasi Hasil Uji t Kelompok Sampel Penelitian

\begin{tabular}{clccccc}
\hline No & $\begin{array}{c}\text { Kelompok } \\
\text { Sampel }\end{array}$ & N & Dk & thitung & t tabel & Simpulan \\
\hline 1 & Eksperimen & 38 & 66 & 5,779 & 2,000 & $\mathrm{H}_{\mathrm{o}}$ ditolak \\
2 & Kontrol & 30 & 66 &
\end{tabular}

Secara deskripstif, kompetensi pengetahuan IPA siswa kelompok eksperimen lebih tinggi dibandingkan dengan kelompok kontrol. Hal ini didasarkan dengan hasil rata-rata gain

skor ternormalisasi kelompok ekperimen $\overline{\boldsymbol{X}}=0,72$. Kemudian di konservasikan pada tabel PAN skala 5 (lima), sehingga diketahui kompetensi pengetahuan IPA kelompok eksperimen pada predikat cukup. Sedangkan hasil rata-rata gain skor ternormalisasi kelompok kontrol

adalah $\overline{\boldsymbol{X}}=0,59$. Kemudian di konservasikan pada tabel PAN skala 5 (lima), sehingga diketahui kompetensi pengetahuan IPA kelompok kontrol pada predikat cukup. Berdasarkan hasil uji hipotesis diperoleh $t_{\text {hitung }}=5,779$ sedangkan pada taraf signifikansi $5 \%$ dan $\mathrm{dk}=66$ diperoleh nilai $\mathrm{t}_{\text {tabel }}=2,000$ sehingga $\mathrm{t}_{\text {hitung }}=5,779>\mathrm{t}_{\text {tabel }}=2,000$. Dengan demikian, hipotesis nol $\left(\mathrm{H}_{0}\right)$ ditolak. Hal ini berarti terdapat perbedaan yang signifikan kompetensi pengetahuan IPA antara kelompok siswa yang dibelajarkan melalui model discovery learning berbasis tri kaya parisuda dan kelompok siswa yang dibelajarkan melalui pembelajaran konvensional pada siswa kelas V SD Negeri Gugus V Mengwi.

Perbedaan yang signifikan kompetensi pengetahuan IPA siswa kelas V SD pada kelompok eksperimen dan kelompok kontrol disebabkan oleh adanya perbedaan perlakuan yang diberikan dalam proses pembelajaran. Pada kelompok eksperimen kegiatan pembelajaran IPA dilakukan dengan menerapkan model discovery learning berbasis Tri Kaya Parisudha. Model discovery learning ini membuat siswa lebih aktif, pembelajaran menjadi lebih bermakna dan efisien. Hal itu karena model discovery learning berbasis Tri Kaya Parisudha menekankan kepada siswa untuk membangun pengetahuannya sendiri dengan memberi suatu masalah-masalah nyata yang akan memberikan pengalaman langsung kepada siswa dalam pemecahannya. Sejalan dengan pendapat Windiani (2017) bahwa pembelajaran discovery ini juga akan yang menuntut guru lebih kreatif menciptakan situasi yang dapat membuat siswa belajar aktif menemukan pengetahuan sendiri. Dalam model pembelajaran Discovery Learning juga menjadikan siswa lebih mudah menerima materi yang disampaikan oleh guru karena dipacu untuk lebih aktif saat proses belajar (Rahmayani, 2019), saat itu guru dapat dianggap sebagai fasilitator dalam pembelajaran.

Faktor yang mempengaruhi kompetensi pengetahuan siswa pada khususnya dapat dilihat dari keaktifan siswa mengikuti proses pembelajaran, selain itu cara guru dalam mengajar juga mempengaruhi kompetensi pengetahuan siswa. Dalam proses pembelajaran IPA di SD, anak-anak perlu diberi kesempatan untuk memiliki kemampuan dalam melakukan penelitian ataupun menganalisis masalah nyata yang dirancang sesuai pertumbuhan perkembangan kognitifnya (Sukaesih, 2018). Penelitian ini dirancang berbasis dengan Tri Kaya Parisudha yangmana memiliki arti yakni (1) Manacika Parisudha yang artinya berpikir yang suci atau yang benar, (2) Wacika Parisudha yang artinya berkata yang benar, dan (3) Kayika Parisudha yang artinya berbuat yang benar. Maksud berpikir, berkata, dan berbuat yang benar ini dianggap benar jika selalu mengacu pada pandangan dharma (kebenaran) (Somawati \& Diantary,2019). Dengan basis Tri Kaya Parisudha ini penting dalam 
penanaman sikap pendidikan anak-anak selama mengikuti pembelajaran IPA di SD utamanya etika anak-anak dengan sekitarnya.

Pada penelitian ini, terdapat pengaruh yang signifikan antara kelas eksperimen dan kelas kontrol menunjukkan bahwa model Discovery Learning berbasis Tri Kaya Parisudha dapat mempengaruhi kompetensi pengetahuan IPA siswa. Hal itu dapat dilihat dari rata-rata dari kelas eksperimen (model Discovery Learning berbasis Tri Kaya Parisudha) dan kelas kontrol (model pembelajaran konvensional). Rata-rata hasil belajar IPA dari kelas eksperimen yaitu 0,719. Sedangkan rata-rata hasil belajar IPA kelas kontrol yaitu 0,586. Ini berarti rata-rata Kompetensi Pengetahuan IPA kelas eksperimen lebih besar dibandingkan dengan rata-rata hasil belajar IPA kelas kontrol (Meksperimen>Mkontrol). Maka dari itu penerapan model Discovery Learning berbasis Tri Kaya Parisudha mampu untuk mendorong siswa aktif belajar. Hal itu pun dikarenakan siswa yang dibelajarkan dengan model pembelajaran discovery learning berbasis Tri Kaya Parisudha lebih mau bekerja sama dengan siswa lain, dan berani untuk mengemukakan pendapat. Siswa lebih termotivasi untuk belajar dan berusaha menyelesaikan semua permasalahan IPA yang ditemui, sehingga pengetahuan yang diperoleh akan lebih diingat oleh siswa serta penguasaan kompetensi pengetahuan yang diinginkan dapat tercapai dengan baik. Model discovery learning juga memungkinkan siswa untuk tahu manfaat dari materi yang dipelajari bagi kehidupannya (Wianjana, 2017).

Penelitian yang mendukung hasil penelitian sebelumnya disampaikan oleh Ni Made Canessia Putri (2018) bahwa hasil penelitiannya menunjukkan nilai rata-rata post test kelompok eksperimen yaitu 84,63, sedangkan nilai rata-rata kelompok post test kelompok kontrol yaitu 74,03. Penelitian selanjutnya yaitu dari Riantari (2017) hasil penelitiannya menunjukkan bahwa nilai rata-rata post test kelas eksperimen yaitu 82,08, sedangkan kelas kontrol dengan nilai rata-rata post test yaitu 71,80 . Begitu pula dengan penelitan yang dilakukan oleh Putri (2018) diperoleh bahwa model discovery learning berbantuan lingkungan berpengaruh terhadap kompetensi pengetahuan siswa kelas V SD. Penelitian oleh Bahari (2018) didapat perbedaan yang signifikan hasil belajar IPA antara kelompok siswa yang dibelajarkan melalui Model Discovery Learning Berbantuan Media Lingkungan Alam Sekitar dan kelompok siswa yang dibelajarkan melalui pembelajaran konvensional. Serta pada penelitian Widiatmika (2017) bahwa terdapat pengaruh yang signifikan kompetensi pengetahuan IPS antara siswa yang dibelajarkan dengan model discovery learning berbantuan media audio visual siswa kelas IV SD.

Melalui pembahasan tersebut, model Discovery Learning berbasis Tri Kaya Parisudha dapat direkomendasikan dalam pembelajaran siswa. Adanya implikasi yang baik dalam penggunaan model Discovery Learning berbasis Tri Kaya Parisudha akan lebih meyakinkan pembaca bahwa model tersebut dapat dijadikan alternatif guru dalam pembelajaran guna mengembangkan mutu pendidikan di Indonesia, khususnya dalam kajian bidang IPA. Dengan penerapan proses pembelajaran yang berbeda antara pembelajaran yang menerapkan model Discovery Learning berbasis Tri Kaya Parisudha ini siswa mampu mengembangkan kreativitas, kemampuan, dan menemukan konsep atau prinsip suatu materi melalui kegiatan penemuan dan siswa lebih memahami materi pembelajaran karena siswa terlibat langsung dalam pelaksanaannya. Hal tersebut sangat mempengaruhi kompetensi pengetahuan IPA siswa.

\section{Simpulan}

Berdasarkan hasil penelitian dan pembahasan, dilihat dari rata-rata gain skor ternormalisasi kelompok eksperimen lebih dari rata-rata gain skor ternormalisasi kelompok kontrol. Serta hasil analisis data menunjukkan thitung lebih besar dari tabel maka dapat disimpulkan bahwa model Discovery Learning berbasis Tri Kaya Parisudha berpengaruh terhadap kompetensi pengetahuan IPA siswa kelas V SD Negeri V Mengwi. Sebagai tindak 
lanjut dari hasil penelitian, maka penelitian ini direkomendasikan kepada pertama, kepala sekolah agar hasil penelitian ini digunakan sebagai referensi untuk melaksanakan penelitian selanjutnya atau menemukan inovasi kegiatan pembelajaran bermakna dan menyenangkan bagi siswa. Kedua guru agar lebih kreatif untuk memberikan fasilitas berupa sumber belajar dan kesempatan yang lebih besar bagi siswa pada pembelajaran dengan menggunakan model discovery learning berbasis tri kaya parisudha sehingga tercipta pembelajaran bermakna dan menyenangkan bagi siswa. Ketiga kepada peneliti lain dapat memanfaatkan hasil penelitian ini sebagai kajian penelitian relevan sebagai penunjang penelitian selanjutnya khususnya pada kompetensi pengetahuan IPA maupun pelajaran lain untuk memperoleh hasil yang baik. model model Discovery Learning berbasis Tri Kaya Parisudha tepat digunakan dalam pengembangan kemampuan berpikir kritis matematika siswa.

\section{Daftar Pustaka}

Agung, A.A. Gede. 2014. Metodologi Penelitian Pendidikan. Yogyakarta: Aditya Media Publishing.

Arikunto, Suharsimi. 2016. Dasar-Dasar Evaluasi Pendidikan. Jakarta: PT Bumi Aksara.

Bahari, N. K. I., Darsana, I. W., \& Putra, D. K. N. S. (2018). Pengaruh Model Discovery Learning Berbantuan Media Lingkungan Alam Sekitar terhadap Hasil Belajar IPA. Jurnal Ilmiah Sekolah Dasar, 2(2), 103. https://doi.org/10.23887/jisd.v2i2.15488.

Cahyana, Gd. Roni. 2019. "Pengaruh Model Pembelajaran Word Square Berbasis Tri Kaya Parisudha Terhadap Hasil Belajar IPA". e-Jurnal PGSD Universitas Pendidikan Ganesha, 32 No $2 . \quad$ diambil dari https://ejournal.undiksha.ac.id/index.php/JISD/article/view/17664/10596 .

Dantes, N. 2017. Desain Eksperimen dan Analisis Data. Depok: Rajawali Pers.

Depdiknas. 2003. Kurikulum 2004 Standar Kompetensi untuk Kelas V Sekolah Dasar. Jakarta: Depdiknas.

Desstya, A. 2018. "Joyfull Learning In Science ( Pelatihan Percobaan Ipa Sederhana Di SD Bener I Dan Bener II )". University Research Colloquium, 2(1), 51-56. diambil dari http://repository.urecol.org/index.php/proceeding/article/view/328.

Dr. Desak Putu Parmiti, M. . (2017). Pengaruh Model Pembelajaran Discovery Learning Berbasis Lingkungan Terhadap Hasil Belajar Ipa Pada Siswa Kelas V Semester Genap Tahun Pelajaran 2016/2017 Di Sd Gugus Ii Kecamatan Tampaksiring. MIMBAR PGSD Undiksha, 5(2). https://doi.org/10.23887/jjpgsd.v5i2.10712.

Drs. Ida Bagus Surya Manuaba, S. (2017). Pengaruh Model Problem Based Learning Berbantuan Media Audio Visual Terhadap Penguasaan Kompetensi Ips. MIMBAR PGSD Undiksha, 5(2), 1-8. https://doi.org/10.23887/jjpgsd.v5i2.11000.

Kristin, Firosalia. 2016. "Analisis Model Pembelajaran Discovery Learning Dalam Meningkatkan Hasil Belajar Siswa SD". Jurnal Pendidikan Dasar PerKhasa, 2 No. 1. diambil dari http://jurnal.stkippersada.ac.id/jurnal/index.php/JPDP/article/view/25/21.

Kodir, Abdul. Menejemen Pembelajaran Saintifik Kurikulum 2013 Pembelajaran yang berpusat pada Siswa. Bandung : Pustaka Setia

Lh, N., Windiani, N., Ganing, N. N., \& Abadi, I. B. G. S. (2017). Pengaruh Model Discovery Learning Berbasis Lingkungan Terhadap Kompetensi Pengetahuan Ipa Kelas Iv Sd Gugus SrikandI Universitas Pendidikan Ganesha. 5(2), 1-10.

Magfirah, A. 2019. "Penggunaan Media Audiovisual Pada Model Inkuiri Terbimbing Terhadap Keterampilan Proses Sains Dan Penguasaan Konsep IPA". Jurnal Pendidikan: Teori Penelitian dan Pengembangan, 4 No. 1. diambil dari https://www.semanticscholar.org/paper/Penggunaan-Media-Audiovisual-pada-ModelInkuiri-dan-Magfirah-Hidayat/e704c5538c5e6c00cd6364c305459984d412abbf.

Muliani, N. K. D. 2019. "Pengaruh Model Pembelajaran Inkuiri Terbimbing Berbantuan 
Video Terhadap Hasil Belajar IPA". e-Jurnal PGSD Universitas Pendidikan Ganesha, 3 No 1 . diambil dari https://ejournal.undiksha.ac.id/index.php/JISD/article/view/17664/10596.

Permendikbud. 2016. Peraturan Menteri Pendidikan Dan Kebudayaan Nomor 22 Tahun 2016 Tentang Standar Proses Pendidikan Dasar dan Menengah. Jakarta: Kemendikbud.

Permendikbud. 2018. Peraturan Menteri Pendidikan Dan Kebudayaan Republik Indonesia Nomor 37 tahun 2018 Perubahan atas peraturan menteri Pendidikan dan Kebudayaan Nomor 24 Tahun 2016 Tentang Kompetensi Inti dan Kompetensi Dasar Pelajaran Pada Kurikulum 2013 pada Pendidikan Dasar dan Pendidikan Menengah. Jakarta: Kemendikbud.

Purnawan, I. (2018). Pengaruh Model Problem Based Learning Berbantuan Media Animasi Terhadap Kompetensi Pengetahuan Ipa Siswa Kelas V. Jurnal Imiah Pendidikan Dan Pembelajaran, 2(2), 211-218. https://doi.org/10.23887/jipp.v2i2.15404

Putri, Ni Made Canessia. 2018. "Pengaruh Model Discovery Learning Berbantuan Lingkungan Terhadap Kompetensi Pengetahuan IPA Siswa Kelas V SD Negeri Gugus II Kuta Utara Thun Ajaran 2017/2018” Volume 2 Tahun 2018. Jurusan Pendidikan Guru Sekolah Dasar. Universitas Pendidikan Ganesha. Tersedia Pada https://ejournal.undiksha.ac.id > index.php > JJPGSD > article > download .

Rahmayani, Aprilia. 2019. "Pengaruh Model Pembelajaran Discovery Learning dengan Menggunakan Mediavideo Terhadap Hasil Belajar". e-Jurnal PGSD Universitas Pendidikan Ganesha, 3 No $2 . \quad$ diambil dari https://ejournal.undiksha.ac.id/index.php/JISD/article/view/17664/10596.

Riantari, Ida Ayu Putu Candrika. 2017. Pengaruh Model Discovery Learning Berbantuan Media Lingkungan Terhadap Kompetensi Pengetahuan IPA Siswa Kelas V SD Gugus II Teuku Umar Denpasar Tahun Pelajaran 2016/2017. Volume 5 Tahun 2017. Jurusan Pendidikan Guru Sekolah Dasar. Universitas Pendidikan Ganesha. Tersedia Pada https://ejournal.undiksha.ac.id > index.php > JJPGSD > article > download.

Rudyanto, Hendra Erick. 2016. "Model Discovery Learning Dengan Pendekatan Saintifik Bermuatan Karakter Untuk Meningkatkan Kemampuan Berpikir Kreatif". Premiere Educandum, 4 No. 1. diambil dari http://ejournal.unipma.ac.id/index.php/PE/article/download/305/277.

Rosarina, Gina. 2016. "Penerapan Model Discovery Learning Untuk Meningkatkan Hasil Belajar Siswa Pada Materi Perubahan Wujud Benda". Jurnal Pena Ilmiah: Vol 1 No. 1. diambil dari https://ejournal.upi.edu/index.php/penailmiah/article/download/3043/pdf.

Rosdiana. 2017. "Pengaruh Penggunaan Model Discovery Learning Terhadap Evektivitas Dan Hasil Belajar Siswa". Jurnal Pendidikan: Teori Penelitian dan Pengembangan, 2 No. 8. diambil dari http://journal.um.ac.id/index.php/jptpp/article/view/9802/4639.

Samatowa, Usman. 2016. Pembelajaran IPA di Sekolah Dasar. Jakarta : Indeks

Suarnaya, Kd. Dwi. 2015. "Pengaruh Model Pembelajaran Tandur Berbasis Kearifan Lokal Tri Kaya Parisudha Terhadap Hail Belajar IPA Siswa Kelas V SD Gugus XV Kecamatan Buleleng Kabupaten Buleleng Tahun Pelajaran 2013/2014" Volume 3 Tahun 2015. Jurusan Pendidikan Guru Sekolah Dasar. Universitas Pendidikan Ganesha. Tersedia Pada https://ejournal.undiksha.ac.id > index.php > JJPGSD > article > download (diakses Senin, 4 November 2019 pukul 08.00).

Sudiasih, N. N., Wibawa, I. M. C., \& Margunayasa, I. G. (2020). "Pengaruh Model Pembelajaran Group Investigation Melalui Lesson Study Terhadap Penguasaan Konsep". Eduhumaniora: Jurnal Pendidikan Dasar, 12(1), 25-36.

Suhardana, K.M. 2007. Tri Kaya Parisudha Bahan Kajian Untuk Berfikir Baik, Berkata Baik dan Berbuat Baik. Surabaya: Paramita. 
Sugiyono. 2017. Statistika untuk Penelitian. Bandung: Alfabeta

Sukardi. (2012). Metodelogi Penelitian Pendidikan. PT Bumi Aksara.

Veronika, A. (2019). Implementasi Ajaran Tri Kaya Parisudha Dalam Membangun Karakter Generasi Muda Hindu Di Era Digital. Jurnal PASUPATI, 6(1), 1. https://doi.org/10.37428/pspt.v6i1.135.

Yuliana, Nabila. 2018. "Penggunaan Model Pembelajaran Discovery Learning Dalam Peningkatan Hasil Belajar Siswa Di Sekolah Dasar". Jurnal Ilmiah Pendidikan dan Pembelajaran: $\quad$ Vol 20 No. $1 . \quad$ diambil dari https://ejournal.undiksha.ac.id/index.php/JIPP/article/download/13851/8671. 